\title{
Peranan Pendidikan dan Pelatihan (Diklat) Pelayanan Prima dalam Meningkatkan Kompetensi Aparatur Pelayanan Publik
}

\author{
Rosdiana $^{1 *}$, Indri Syahfitri ${ }^{2}$ \\ ${ }^{1}$ Program Studi Pendidikan Masyarakat, Universitas Negeri Medan \\ ${ }^{2}$ Kantor Diklat Kota Medan \\ *Korespondensi Penulis, Email: rosdianafip@gmail.com
}

\begin{abstract}
Abstrak
Penelitian ini bertujuan untuk melihat peranan diklat pelayanan prima dalam meningkatkan kompetensi aparatur pelayanan publik di Kantor Camat Medan Helvetia. Jenis penelitian yang digunakan adalah penelitian deskriptif kualitatif. Objek penelitian ini adalah petugas front liner yang telah mengikuti diklat pelayanan prima tahun 2012 dan 2015, pimpinan dari petugas front liner, dan masyarakat yang mendapatkan pelayanan dari petugas front liner yang diteliti. Data yang di peroleh dalam penelian ini di ukur menggunakan teknik pengumpulan data dengan wawancara dan dokumentasi. Data dianalisis menggunakan reduksi data, penyajian data, penarikan kesimpulan dan verifikasi. Hasil analisis data yang diperoleh bahwa diklat pelayanan prima berperan dalam meningkatkan kompetensi aparatur pelayanan publik seperti mampu berkomitmen dengan menunjukan sikap lebih mengutamakan masyarakat, melakukan evaluasi pada setiap program pekerjaan. Kesimpulan hasil analisis data diperoleh bahwa pendidikan dan pelatihan (diklat) pelayanan prima sangat berperan dalam meningkatkan kompetensi aparatur pelayanan publik dalam melayani masyarakat di Kantor Camat Medan Helvetia.
\end{abstract}

Kata kunci: Pelatihan, Pelayanan Prima, Aparatur Pelayanan Publik

\begin{abstract}
This study aims to look at the role of excellent service training in improving the competence of public service personnel in the Helvetia District Head Office. The type of research used is descriptive qualitative research. The object of this research is front liner officers who have participated in excellent service training in 2012 and 2015, leaders of front liner officers, and people who get service from the front liner officers studied. The data obtained in this study was measured using data collection techniques with interviews and documentation. Data were analyzed using data reduction, data presentation, drawing conclusions and verification. The results of data analysis obtained that prime service training plays a role in improving the competence of public service apparatus such as being able to commit to showing a more public attitude, evaluating each work program. The conclusion of the results of the data analysis is that education and training (training) of excellent service plays an important role in improving the competence of the public service apparatus in serving the community at the Helvetia District Head Office.
\end{abstract}

Keywords: Training, Excellent Service, Public Service Apparaturs 
Journal of Millennial Community, 1 (1), March 2019

Rosdiana, Indri Syahfitri

\section{PENDAHULUAN}

Menurut Undang-Undang No 25 Tahun 2009 tentang Pelayanan Publik adalah "Kegiatan atau rangkaian kegiatan dalam rangka pemenuhan kebutuhan pelayanan sesuai dengan peraturan perundang-undangan bagi setiap warga Negara dan penduduk atas barang, jasa, dan/atau pelayanan administratif yang disediakan oleh penyelenggara pelayanan publik". Mendapatkan pelayanan publik yang baik merupakan hak warga negara yang sudah seharusnya diperoleh berdasarkan pada norma-norma hukum dan peraturan-peraturan yang mengaturnya secara jelas.

Kegiatan diklat aparatur merupakan peningkatan kompetensi aparatur agar mampu menghasilkan kinerja yang optimal melalui transfer pengetahuan, sikap dan keterampilan. Diadakannya kegiatan diklat tersebut diharapkan dapat meningkatkan pengetahuan, keterampilan dan sikap dari aparatur pelayanan publik. Untuk itulah peneliti ingin melihat apakah diklat yang selama ini diadakan pemerintah telah mencapai tujuan dari diklat itu sendiri.

Beberapa upaya pemerintah telah dilakukan untuk meningkatkan kompetensi aparatur pelayanan publik. Salah satunya dengan mengadakan pendidikan dan pelatihan (diklat) pelayanan prima. Pendidikan dan pelatihan merupakan suatu kebutuhan guna mendukung salah satu bentuk kegiatan peningkatan kompetensi dan merupakan bagian integral dalam Manajemen Sumber Daya Manusia (SDM). Dalam hal penyelenggaran pendidikan dan pelatihan diperlukan pengelolaan secara efektif dan adanya koordinasi yang tepat diantara para pegawai atau panitia penyelenggara terhadap diklat yang diselenggarakan sehingga dapat menghasilkan SDM yang handal dan memiliki kompetensi tertentu sesuai dengan kebutuhan organisasi.

Tujuan dari penelitian ini adalah untuk mengetahui peranan pendidikan dan pelatihan (diklat) pelayanan prima dalam meningkatkan kompetensi aparatur pelayanan publik di Kantor Camat Medan Helvetia.

\section{METODE PENELITIAN}

Jenis penelitian adalah deskriptif kualitatif. Subjek penelitian ditentukan Page 10 berdasarkan ciri dan karakteristik yang diperlukan yaitu pegawai/aparatur pelayanan publik yang sudah mengikuti diklat pelayanan prima dan telah mendapatkan Surat Tanda Tamat Pendidikan dan Pelatihan (STTPP) serta yang bertugas sebagai Front Liner di Kantor Camat Medan Helvetia, Pimpinan dari aparatur pelayanan publik, dan warga masyarakat yang mendapatkan pelayanan dari pegawai aparatur pelayanan publik yang telah mengikuti diklat pelayanan prima.

Teknik pengumpulan data dalam penelitian ini adalah dengan menggunakan wawancara dan dokumentasi. Analisis data dilakukan dengan tiga langkah yaitu reduksi data, penyajian data, penarikan kesimpulan dan verifikasi.

Penelitian ini dilaksanakan di Kantor Camat Medan Helvetia. Jln. Beringin X no. 2 Medan. Penelitian dilaksanakan selama 2 bulan mulai dari awal bulan Oktober sampai akhir bulan November.

\section{HASIL PENELITIAN DAN PEMBAHASAN}

Hasil Penelitian

Kecamatan Medan Helvetia adalah salah satu dari 21 kecamatan yang berada di Wilayah Kota Medan memiliki luas \pm 1.156.147 Ha dan merupakan pecahan dari Kecamatan Medan Sunggal. Kecamatan Medan Helvetia terbagi menjadi 7 (tujuh) Kelurahan dan 88 lingkungan dengan status Kelurahan Swasembada. Luas wilayah Kecamatan Medan Helvetia adalah \pm 1.156.147 Ha. Visi Kecamatan yaitu : "Mewujudkan kecamatan Medan Helvetia sebagai miniatur Kota Medan yang berdaya saing, nyaman, peduli dan sejahtera". Misi dari Kecamatan Medan Helvetia adalah sebagai berikut : "Meningkatkan peran aktif birokrasi Kecamatan Medan Helvetia yang efisien dan berfungsi sebagai pelayan masyarakat, mendorong terciptanya rasa 
Journal of Millennial Community, 1 (1), March 2019

Rosdiana, Indri Syahfitri

aman dalam dinamika kehidupan masyarakat serta terciptanya kerukunan hidup antar umat beragama".

Pembahasan

Berdasarkan hasil wawancara terhadap petugas front liner penulis dapat menyimpulkan bahwa dengan diselenggarakannya pendidikan dan pelatihan (diklat) pelayanan prima diharapkan dapat meningkatkan kompetensi kinerja pegawai yang bertugas memberikan pelayanan kepada masyarakat khususnya di Kantor Camat Medan Helvetia. Kompetensi aparatur dapat dijabarkan dalam tujuh bagian yaitu komitmen, integritas, tanggungjawab, kecakapan dan keramahan, mengerti kebutuhan palanggan/masyarakat, daya tanggap dan empati, etika dan moralitas. Sebagai aparatur yang melayani publik/masyarakat tentunya dituntut untuk dapat menguasai ketiga bagian dari kompetensi tersebut. Seorang petugas front liner harus mempunyai pengetahuan tentang apa saja tugas-tugas yang mencakup pelayanan publik, baik dalam pemahaman tentang pelayanan prima itu sendiri maupun pemahaman tentang tugas dan fungsi pokok kedudukannya dalan instansi tersebut.

Selain pengetahuan, seorang yang bertugas sebagai pemberi layanan kepada masyarakat harus mempunyai keterampilan dalam menyelesaikan tugas tepat waktu, memahami prosedur dalam pembuatan catatan sipil, keterampilan menyampaikan informasi agar tepat sasaran dan tidak rumit, keterampilan mengaplikasikan materi diklat dalam pekerjaan, serta keterampilan dalam mengoperasikan alat-alat pendukung pekerjaan. Pengetahuan dan keterampilan merupakan bagian dalam kompetensi seseorang, namun dalam kedudukan sebagai seorang front liner pengetahuan dan keterampilan saja belum cukup dikatakan sebagai orang yang berkompeten dalam menjalankan tugas sebagai aparatur pelayanan publik. Oleh karena itu, untuk mengimbangi pengetahuan dan keterampilan hendaknya seorang petugas pelayanan publik harus memiliki sikap yang benar-benar menjiwai pekerjaan sebagai pemberi layanan kepada pelanggan/masyarakat.

Sikap tersebut yang menjadi awal penilaian apakah pelanggan/masyarakat merasa puas terhadap pelayanan yang diberikan atau tidak. Sikap ramah, sopan santun, menyapa dan memberi salam merupakan tindakan yang sangat mudah dilakukan namun terkadang sulit untuk diaplikasikan. Hal inilah yang membuat kompetensi seseorang dalam sikap paling diharapkan selain dari kompetensi dalam pengetahuan dan keterampilan.

Tujuan

khusus diselenggarakannya diklat pelayanan prima ialah agar dapat menghasilkan petugaspetugas pelayanan publik yang kompeten dalam pengetahuan, keterampilan dan sikap dalam menjalankan tugas sebagai pemberi layanan kepada masyarakat khususnya pada pegawai pemerintah. Oleh karena itu, diklat pelayanan prima yang diselenggarakan oleh Kantor Pendidikan dan Pelatihan Kota Medan mulai tahun 2012, 2014, dan 2015 sangat berperan dalam meningkatkan kompetensi kinerja pegawai khususnya pegawai pemerintah yang bertugas sebagai aparatur pelayanan publik baik di Kelurahan, Kecamatan, maupun instansi Pemerintah Kota Medan lainnya.

\section{SIMPULAN}

Berdasarkan penelitian yang telah dilakukan, dapat disimpulkan bahwa pendidikan dan pelatihan (diklat) pelayanan prima sangat berperan dalam meningkatkan kompetensi kinerja aparatur pelayanan publik di Kecamatan Medan Helvetia. Petugas front liner yang memberi layanan kepada masyarakat telah menerapkan materi-materi yang didapat pada saat mengikuti diklat pelayanan prima dalam menjalankan tugas sebagai seorang aparatur pelayanan publik. Petugas front liner sudah lebih memahami dalam mengutamakan masyarakat, melakukan evaluasi pada setiap program kegiatan, dapat bersikap konsisten dan dapat bertanggung jawab dalam melaksanakan tugas melayani masyarakat. Aparatur 
Journal of Millennial Community, 1 (1), March 2019

Rosdiana, Indri Syahfitri

pelayanan publik sudah dapat meningkatkan kualitas pelayanan dengan cara melakukan perbaikan secara berkelanjutan.

Kemudian mengenai kecakapan dan keramahan, petugas pelayanan publik juga sudah mampu menerapkan sistem kerja yang efektif dan efisien sesuai dengan Standar Operasional Prosedur (SOP) yang membuat pekerjaan dapat terselesaikan tepat waktu, mampu mengoperasikan alatalat pendukung pekerjaan. Petugas aparatur pelayan publik juga sudah menerapkan sistem 3S (senyum, salam, sapa) dalam menyambut dan memberikan pelayanan kepada masyarakat, serta bersikap ramah dan sopan santun baik dari penampilan maupun perkataan.

\section{DAFTAR PUSTAKA}

Alfian, dkk. 2014. Undang-Undang tentang Pelayanan Publik dan Keterbukaan Informasi Publik. Yogyakarta: Saufa.

Daryanto dan Ismanto Setyobudi. 2014. Konsumen dan Pelayanan Prima. Yogyakarta : Gava Media.

Hardiansyah. 2011. Kualitas Pelayanan Publik. Yogyakarta: Gava Media.

Hasibuan, Melayu SP. 2001. Manajemen Sumber Daya Manusia Cetakan Kesembilan. Jakarta: Gunung Agung.

Kirom, Bahrul. 2010. Mengukur kinerja Pelayanan dan Kepuasan Konsumen. Bandung: Pustaka Reka Cipta.

Lembaga Administrasi Negara. 2012. Modul Diklat Pelayanan Publik. Jakarta : Pusdiklat SPIMNAS Bidang Teknik
Manajemen dan Kebijakan Pembangunan.

Martoyo, Susilo. 2001.Manajemen Sumber Daya Manusia, Edisi Keempat. Yogyakarta: BPFE UGM.

Moenir, H.A.S. 2002. Manajemen Pelayanana Umum Di Indonesia. Page|12 Jakarta: Bumi Aksara.

Penyelenggara. 2012. Laporan Penyelenggaraan Diklat Pelayanan Prima Bagi Aparatur Pelayanan Publik di Lingkungan Pemerintah Kota Medan Tahun Anggaran 2012. Medan: Kantor Pendidikan dan Pelatihan kota Medan.

Penyelenggara. 2013.2 Laporan Penyelenggaraan Diklat Pelayanan Prima Bagi Aparatur Pelayanan Publik di Lingkungan Pemerintah Kota Medan Tahun Anggaran 2013. Medan: Kantor Pendidikan dan Pelatihan kota Medan.

Penyelenggara. 2015.2 Laporan Penyelenggaraan Diklat Pelayanan Prima Bagi Aparatur Pelayanan Publik di Lingkungan Pemerintah Kota Medan Tahun Anggaran 2015. Medan: Kantor Pendidikan dan Pelatihan kota Medan.

Ratminto dan Atik Septi Winarsih. 2010. Manajemen Pelayanan. Yogyakarta : Pustaka Pelajar.

Sugiyono. 2007. Metode Penelitian Pendidikan Pendekatan Kuantitatif, Kualitatif, dan R\&D. Bandung : Alfabeta.

Sugiyono. 2013. Metode Penelitian Pendidikan Pendekatan Kuantitatif, Kualitatif, dan R\&D. Bandung : Alfabeta.

Wibowo. 2011. Manajemen Kinerja. Jakarta: Rajagrafindo Persada. 